\title{
ORIGINAL ARTICLE Prediction and evaluation of resting energy expenditure in a large group of obese outpatients
}

\author{
M Marra, I Cioffi, R Sammarco, C Montagnese, M Naccarato, V Amato, F Contaldo and F Pasanisi
}

\begin{abstract}
BACKGROUND/OBJECTIVES: The aim of this study was to compare resting energy expenditure (REE) measured (MREE) by indirect calorimetry (IC) and REE predicted (PREE) from established predictive equations in a large sample of obese Caucasian adults. SUBJECTS/METHODS: We evaluated 1851 obese patients (body mass index (BMI) $>30 \mathrm{~kg} \mathrm{~m}^{-2}$ ) aged between $18 \mathrm{a}$ and 65 years. Data were obtained by comparing MREE with PREE, derived from different equations, within and between normal weight and obese groups. The mean differences between PREE and MREE as well as the accuracy prediction within $\pm 10 \%$ level were investigated in the whole sample and in three subgroups, classified by BMI (Group 1=30-39.9 $\mathrm{kg} \mathrm{m}^{-2}$; Group 2=40-49.9 $\mathrm{kg} \mathrm{m}^{-2}$; Group 3>50 $\mathrm{kg} \mathrm{m}^{-2}$ ).

RESULTS: We observed that FAO, Henry and Muller3 (body composition (BC)) equations provided good mean PREE-MREE (bias $-0.7,-0.3$ and $0.9 \%$; root mean standard error (RMSE) 273, 263 and 269 kcal per day, respectively); HB and Henry equations were more accurate individually (57 and 56.9\%). Only the Muller1 (BC) equation gave the lowest PREE-MREE difference (bias - $1.7 \%$; RMSE $228 \mathrm{kcal}$ per day) in females, while Johnstone and De Lorenzo equations were the most accurate (55.1 and $54.8 \%)$. When the sample was split into three subgroups according to BMI, no differences were found in males; however, the majority of the equations included in this study failed to estimate REE in severely obese females (BMI $>40 \mathrm{~kg} \mathrm{~m}^{-2}$ ). Overall, prediction accuracy was low $(\sim 55 \%)$ for all predictive equations, regardless of BMI.

CONCLUSIONS: Different established equations can be used for estimating REE at the population level in both sexes. However, the accuracy was very low for all predictive equations used, particularly among females and when BMI was high, limiting their use in clinical practice. Our findings suggest that the validation of new predictive equations would improve the accuracy of REE prediction, especially for severely obese subjects $\left(\mathrm{BMI}>40 \mathrm{~kg} \mathrm{~m}^{-2}\right)$.
\end{abstract}

International Journal of Obesity (2017) 41, 697-705; doi:10.1038/ijo.2017.34

\section{INTRODUCTION}

Obesity is a state of energy imbalance. As such, the assessment of resting energy expenditure (REE) provides useful information for body weight management. As a matter of fact, knowledge of the individual energy expenditure appears to be necessary for providing adequate dietary advice since REE generally contributes $60-70 \%$ of total energy expenditure. ${ }^{1}$ In clinical practice, the evaluation of REE in obese subjects provides the background to prescribe appropriate energy-restricted diets, ${ }^{2}$ thus improving long-term patient compliance.

REE can be measured by indirect calorimetry (IC) or estimated from predictive equations. The measurement of REE by IC is a noninvasive method that measures oxygen consumption and carbon dioxide production. IC is generally considered the gold standard in clinical practice. However, potential drawbacks such as the high cost of equipment, the time required to take correct measurements and the lack of qualified staff have prevented the widespread use of IC in most clinical settings.

Alternatively, predictive equations are widely used to estimate REE. These equations are typically based on anthropometric variables; however, many variables such as age, sex, weight, height and body composition (FM: fat mass and FFM: fat-free mass) as well as ethnicity, environmental temperature, drug treatment and so on can affect REE prediction.
Although several equations have been developed, data show conflicting results on which is the most appropriate to use for predicting REE in obese subjects, especially for severely obese people (body mass index $(\mathrm{BMI})>40 \mathrm{~kg} \mathrm{~m}^{-2}$ ). Some of the most commonly used predictive equations were generated in normalweight populations ${ }^{3-5}$ that included few or no obese ${ }^{6}$ or severely obese subjects. ${ }^{7}$ It can be assumed that most of the established REE predictive equations do no accurately predict REE in obese subjects. ${ }^{8}$ For example, Horie et $a .^{9}{ }^{9}$ formulated a new equation specifically to estimate REE in 120 obese subjects $\left(B M I>35 \mathrm{~kg} \mathrm{~m}^{-2}\right)$ as no published equation accurately predicted REE in this population when compared to REE measured by IC. Therefore, much research is still needed in this area.

It is also unclear whether body composition variables, such as FFM and FM, could enhance the accuracy of REE predictive equations in severely obese people. For example, when body composition variables were assessed by bioelectrical impendence analysis (BIA), the accuracy of REE was highly dependent on the equations used to calculate percent FFM. ${ }^{7,10}$

Thus, in the present study, we sought to compare REE measured (MREE) by IC and REE predicted (PREE) by commonly cited predictive equations in a sample of 1851 obese, Caucasian adults. In addition to assessing the accuracy of these prediction equations in the entire sample, we also tested whether splitting our sample

Internal Medicine and Clinical Nutrition Unit, Department of Clinical Medicine and Surgery, Interuniversity Centre for Obesity and Eating Disorders (CISRODCA), Federico II University of Naples, Naples, Italy. Correspondence: Dr M Marra, Internal Medicine and Clinical Nutrition Unit, Department of Clinical Medicine and Surgery, Interuniversity Centre for Obesity and Eating Disorders (CISRODCA), Federico II University of Naples, Via S. Pansini 5, Naples 80131, Italy.

E-mail: marra@unina.it

Received 22 June 2016; revised 3 January 2017; accepted 22 January 2017; accepted article preview online 6 February 2017; advance online publication, 28 February 2017 
into three subgroups according to BMI could improve the accuracy of REE prediction.

\section{MATERIALS AND METHODS}

\section{Patients}

A group of 1851 Caucasian Italian obese patients, 1181 females and 670 males, aged between 18 and 65 years old with $\mathrm{BMI}>30 \mathrm{~kg} \mathrm{~m}^{-2}$ were recruited for the study. Exclusion criteria were as follows: current participation in a weight loss program, presence of metabolic, inflammatory and/or endocrine diseases, pregnancy, lactation or daily use of prescription medication or drugs known to influence energy metabolism.

Data were collected between 2005 and 2015 from outpatients undergoing routine procedures to evaluate nutritional status (including full biochemistry, bio-impedance analysis and IC) at the Internal Medicine and Clinical Nutrition Unit of the Federico II University Hospital in Naples, Italy. The study was conducted in according to the Declaration of Helsinki and received the approval of the Local Ethical Committee; in addition, informed consent was obtained from all patients.

All measurements were performed early in the morning after a fasting period of 10-12 h according to standardized conditions, that is, abstention from alcohol, smoking and rigorous physical activity for $24 \mathrm{~h}$ prior to the assessment. According to the protocol, smoking was not allowed for occasional smokers on the day of the test; however, to avoid any confounding factors, current smokers asked to keep their current smoking habits. ${ }^{11}$

Data were excluded from analysis if the respiratory quotient was outside the expected physiological range (0.71-1.00), when measured REE was \pm 3 s.d.'s outside the mean REE or in the presence of peripheral oedema.

\section{Anthropometry}

Body weight and height were measured to the nearest $0.1 \mathrm{~kg}$ and $0.5 \mathrm{~cm}$, respectively. Measurements were taken while the subject wore light clothes and no shoes using a platform beam scale with a built-in stadiometer (Seca 709; Seca, Hamburg, Germany). BMI was calculated as body weight expressed as kilograms divided by squared height reported in meters.

\section{Body composition}

Body composition $(\mathrm{BC})$ was evaluated by bioelectrical impedance analysis $(B I A)^{12}$ performed at $50 \mathrm{kHz}$ (Human Im Plus II, DS Medica, Milan, Italy) at room temperature $\left(22-25^{\circ} \mathrm{C}\right)$. Measurements were carried out on the nondominant side of the body, in the post-absorptive state, and after being in the supine position for $20 \mathrm{~min}$. Subjects voided prior to measurements. The measured BIA variables were resistance $(R)$ and reactance $(X \mathrm{C}),{ }^{13}$ while
FFM and FM were estimated using the predictive equation developed by Kushner. ${ }^{14}$

\section{Indirect calorimetry}

REE was measured by $\mathrm{IC}^{15}$ using a canopy system (V max29, Sensor Medics, Anaheim, CA, USA) at an ambient temperature of $23-25^{\circ} \mathrm{C}$. The instrument was checked by burning ethanol, while oxygen and carbon dioxide analyzers were calibrated using nitrogen and standardized gases (mixtures of nitrogen, carbon dioxide and oxygen) on test day. Women were evaluated in the follicular phase to avoid any potential effects of the menstrual cycle on REE. Subjects lay down on the bed, in a quiet environment for a 15-min adaptation period. Afterwards, oxygen consumption and carbon dioxide production were measured for $45 \mathrm{~min}$. The interday coefficient of variation (as determined in six obese individuals on consecutive days) was less than 3\%. Energy expenditure was calculated using the abbreviated Weir's formula, neglecting protein oxidation. $^{16}$

\section{REE predictive equations}

The majority of REE prediction equations commonly used for adults (15 based on anthropometric parameters and 10 on BC) were selected as follows: predictive equations for normal-weight subjects (Harris and Benedict, ${ }^{3}$ Schofield, ${ }^{4}$ FAO/WHO/UNU, ${ }^{5}$ Henry ${ }^{17}$ and Muller et al. ${ }^{18}$ ), for both normal-weight and obese subjects (Mifflin et al., ${ }^{6}$ Muller et al., ${ }^{18}$ De Lorenzo et al., ${ }^{19}$ Owen et al., ${ }^{20,21}$ Korth et al., ${ }^{22}$ Johnstone et al. ${ }^{23}$ and Livingstone and Kohlstadt ${ }^{24}$ ) and for obese subjects only (Lazzer et al., ${ }^{7}$ Muller et al., ${ }^{18}$ Huang et al. ${ }^{25}$ and Bernstein et al. ${ }^{26}$; see Supplementary Appendix). We applied all the equations, regardless of the weight status of the patient.

\section{Data analysis}

All data are presented as means \pm s.d.'s. Statistical significance is defined as $P<0.05$. One-way analysis of variance was used to compare data between sexes. Accuracy of the predictive equations at both the population and individual levels were calculated. Bias, or the average percent difference between the PREE and MREE, was defined at $\pm 5 \%$ and used as a measure of accuracy at the group level. ${ }^{27,28}$

The percentage of patients with a predicted REE within $90-110 \%$ of the measured REE was used as a measure of accuracy at the individual level. Specifically, values lower than $90 \%$ were classified as underpredictions, and values higher than $110 \%$ as overpredictions. The root mean squared error (RMSE) was used to define the predictions obtained with this model. Comparisons of measured versus calculated REE were performed while taking into account the Bland-Altman plots to estimate limits of agreement. ${ }^{29}$ All statistical analyses were performed using SPSS IBM ver.18 (Chicago, IL, USA).

Table 1. Patient characteristics according to sex and BMI

\begin{tabular}{|c|c|c|c|c|c|c|c|c|}
\hline & \multicolumn{2}{|c|}{ Group 1} & \multicolumn{2}{|c|}{ Group 2} & \multicolumn{2}{|c|}{ Group 3} & \multicolumn{2}{|c|}{ All } \\
\hline & $M$ & $F$ & $M$ & $F$ & $M$ & $F$ & $M$ & $F$ \\
\hline$N$ & 249 & 494 & 282 & 498 & 139 & 189 & 670 & 1181 \\
\hline Age (y) & $36.5 \pm 11.2$ & $34.9 \pm 12.5$ & $34.1 \pm 10.7$ & $34.9 \pm 11.7$ & $33.8 \pm 10.0^{a}$ & $36.9 \pm 10.2$ & $34.9 \pm 10.8$ & $35.2 \pm 11.8$ \\
\hline Weight (kg) & $111 \pm 12^{a}$ & $92.0 \pm 10.5$ & $137 \pm 13^{a}$ & $116 \pm 12$ & $166 \pm 18^{a}$ & $144 \pm 16$ & $133 \pm 25^{\mathrm{a}}$ & $111 \pm 22$ \\
\hline Height (cm) & $176 \pm 7^{a}$ & $162 \pm 6$ & $175 \pm 7^{a}$ & $162 \pm 6$ & $173 \pm 7^{a}$ & $160 \pm 6$ & $175 \pm 7^{a}$ & $161 \pm 6$ \\
\hline BMI $\left(\mathrm{kg} \mathrm{m}^{-2}\right)$ & $35.7 \pm 2.9^{a}$ & $35.2 \pm 2.90$ & $44.8 \pm 2.9$ & $44.5 \pm 2.8$ & $55.5 \pm 4.5$ & $55.8 \pm 5.4$ & $43.6 \pm 8.0^{a}$ & $42.4 \pm 8.0$ \\
\hline MREE $\left(\mathrm{kcal} \mathrm{d}^{-1}\right)$ & $2291 \pm 334^{a}$ & $1757 \pm 247$ & $2651 \pm 401^{a}$ & $2125 \pm 302$ & $2998 \pm 356$ & $2484 \pm 343$ & $2589 \pm 452^{a}$ & $2028 \pm 388$ \\
\hline $\mathrm{RQ}$ & $0.860 \pm 0.068$ & $0.855 \pm 0.063$ & $0.848 \pm 0.066$ & $0.844 \pm 0.074$ & $0.850 \pm 0.06$ & $0.837 \pm 0.078$ & $0.852 \pm 0.067$ & $0.847 \pm 0.070$ \\
\hline FFM (kg) & $69.5 \pm 8.40^{\mathrm{a}}$ & $50.6 \pm 6.5$ & $77.6 \pm 10.3^{a}$ & $57.5 \pm 6.7$ & $86.2 \pm 12.4^{a}$ & $65.9 \pm 8.3$ & $76.6 \pm 12.1^{a}$ & $55.9 \pm 8.7$ \\
\hline FM (kg) & $41.0 \pm 9.7$ & $41.5 \pm 7.6$ & $59.2 \pm 10.0$ & $58.8 \pm 8.6$ & $77.8 \pm 14.2$ & $78.0 \pm 12.1$ & $56.6 \pm 18.0^{a}$ & $54.6 \pm 15.7$ \\
\hline FM (\%) & $36.8 \pm 6.7^{a}$ & $44.9 \pm 5.4$ & $43.2 \pm 5.7^{a}$ & $50.5 \pm 4.3$ & $47.3 \pm 6.27^{a}$ & $54.1 \pm 4.3$ & $41.7 \pm 7.4^{a}$ & $48.7 \pm 5.9$ \\
\hline
\end{tabular}

Abbreviations: $B M I$, body mass index; $F$, female; FFM, fat-free mass; $F M$, fat mass; $M$, male; $M R E E$, measured resting energy expenditure; RQ, respiratory quotient. Data are expressed as mean \pm s.d. Group $1=$ BMl 30-39.9 kg m${ }^{-2}$; Group $2=$ BMl $40-49.9 \mathrm{~kg} \mathrm{~m}^{-2}$; Group $3=\mathrm{BMl}>50$. ${ }^{\mathrm{a}}><0.05$ between sexes. 


\begin{tabular}{|c|c|c|c|c|c|c|}
\hline \multirow[t]{2}{*}{$\begin{array}{l}\text { REE predictive } \\
\text { equations }\end{array}$} & \multicolumn{2}{|c|}{$\begin{array}{l}\text { Diff predicted- } \\
\text { measured kcal } \\
\text { per day }\end{array}$} & \multicolumn{4}{|c|}{ Mean } \\
\hline & Mean & s.d. & $\begin{array}{c}\mathrm{Bias}^{\mathrm{a}} \\
\%\end{array}$ & $\begin{array}{c}\text { Max } \\
\text { negative } \\
\text { error \% }\end{array}$ & $\begin{array}{c}\text { Max } \\
\text { positive } \\
\text { error \% }\end{array}$ & $\begin{array}{c}\text { RMSE } \\
k c a l \\
\text { per day }\end{array}$ \\
\hline \multicolumn{7}{|c|}{ Equation for normal-weight subjects } \\
\hline $\mathrm{HB}$ & -76 & 317 & -1.7 & -31.1 & 32.4 & 257 \\
\hline Henry & -38 & 331 & -0.3 & -30.8 & 36.7 & 263 \\
\hline Muller1 & -394 & 373 & -13.2 & -40.8 & 27.1 & 434 \\
\hline Muller1 (BC) & -195 & 349 & -5.6 & -36 & 35.1 & 311 \\
\hline Schofield & -75 & 344 & -1.6 & -32 & 37.8 & 276 \\
\hline FAO & -52 & 343 & -0.7 & -31.4 & 38.8 & 273 \\
\hline \multicolumn{7}{|c|}{ Equation for both normal weight and obese subjects } \\
\hline Muller2 & 28.5 & 331 & 3 & -292 & 45.9 & 271 \\
\hline Muller2 (BC) & -231 & 349 & -7 & -36.4 & 33.1 & 326 \\
\hline Mifflin & -342 & 321 & -11.9 & -38.9 & 20.6 & 377 \\
\hline Mifflin (BC) & -668 & 383 & -24.4 & -50.4 & 10.5 & 672 \\
\hline De Lorenzo & -102 & 316 & -2.7 & -32 & 31.0 & 261 \\
\hline Owen & -352 & 324 & -12.1 & -38.1 & 19.8 & 383 \\
\hline Owen (BC) & -592 & 385 & -21.5 & -48.7 & 15.5 & 604 \\
\hline Korth & -116 & 323 & -2.9 & -32.8 & 35.0 & 268 \\
\hline Korth (BC) & -318 & 390 & -10.7 & -41.7 & 31.4 & 400 \\
\hline Johnstone (BC) & -228 & 331 & -7.6 & -35.8 & 25.8 & 316 \\
\hline Livingstone & -370 & 335 & -12.7 & -39.3 & 22.9 & 402 \\
\hline \multicolumn{7}{|c|}{ Equation for obese subjects } \\
\hline Lazzer & -169 & 317 & -5.0 & -32.5 & 28.9 & 280 \\
\hline Lazzer (BC) & -343 & 377 & -11.5 & -40.4 & 27.6 & 402 \\
\hline Muller3 & 96 & 327 & 5.5 & -27.3 & 48.9 & 282 \\
\hline Muller3 (BC) & -22 & 331 & 0.9 & -31.1 & 42.9 & 269 \\
\hline Huang & -265 & 322 & -8.8 & -35.1 & 25.5 & 326 \\
\hline Huang (BC) & -288 & 320 & -9.8 & -36.4 & 22.5 & 338 \\
\hline Bernstein & -568 & 322 & -21.1 & -46.3 & 7.3 & 572 \\
\hline Bernstein (BC) & -740 & 349 & -27.5 & -50.8 & 0.2 & 740 \\
\hline \multicolumn{7}{|c|}{$\begin{array}{l}\text { Abbreviations: BC, body composition; Max, maximum; REE, resting } \\
\text { energy expenditure; RMSE, root mean square error. Average REE } \\
\text { measured with indirect calorimetry }=2589 \pm 452 \mathrm{kcal} \text { per day. }{ }^{\mathrm{a}} \text { Mean } \\
\text { percentage error between predictive equations and measured } \\
\text { value. }\end{array}$} \\
\hline
\end{tabular}

\section{RESULTS}

Significant differences in anthropometric, body composition and MREE data of the full study group as well as the BMl subgroups (Group 1=30-39.9 $\mathrm{kg} \mathrm{m}^{-2}$; Group 2=40-49.9 $\mathrm{kg} \mathrm{m}^{-2}$; Group 3 $>50 \mathrm{~kg} \mathrm{~m}^{-2}$ ) are summarized in Table 1.

We evaluated differences in the following measures: PREEMREE in kcal per day, percent bias, the maximum values for negative and positive error, the RMSE in kcal per day, percent accurate predictions, percent underpredictions and percent overpredictions. Bland-Altman plots of PREE-MREE differences versus mean PREE-MREE were performed.

The Muller3 (BC) equation revealed the lowest PREE-MREE difference in both males ( $-22 \mathrm{kcal}$ per day) and females ( $+47 \mathrm{kcal}$ per day). In males, we observed that FAO/WHO/UNU, Henry and Muller3 (BC) equations had bias percentages under 1\% (bias - 0.7, -0.3 and 0.9\%; RMSE 273, 263 and 269 kcal per day, respectively; Table 2a). In females, none of the predictive equations considered in this study showed a percent bias lower than $1 \%$. Of those equations tested, Muller1 $(\mathrm{BC})$ gave the lowest value $(-1.7 \%$; RMSE $228 \mathrm{kcal}$ per day; Table $2 \mathrm{~b})$.
Table 2 b. Evaluation of REE with different predictive equations in 1181 females based on differences predicted-measured, bias and RMSE

\begin{tabular}{|c|c|c|c|c|c|c|}
\hline \multirow[t]{2}{*}{$\begin{array}{l}\text { REE predictive } \\
\text { equations }\end{array}$} & \multicolumn{2}{|c|}{$\begin{array}{l}\text { Diff predicted- } \\
\text { measured kcal } \\
\text { per day }\end{array}$} & \multicolumn{4}{|c|}{ Mean } \\
\hline & Mean & s.d. & $\begin{array}{c}B I A S^{\mathrm{a}} \\
\%\end{array}$ & $\begin{array}{c}\text { Max } \\
\text { negative } \\
\text { error \% }\end{array}$ & $\begin{array}{c}\text { Max } \\
\text { positive } \\
\text { error \% }\end{array}$ & $\begin{array}{c}\text { RMSE } \\
\text { kcal } \\
\text { per day }\end{array}$ \\
\hline \multicolumn{7}{|c|}{ Equation for normal-weight subjects } \\
\hline $\mathrm{HB}$ & -181 & 258 & -7.2 & -32.9 & 40.5 & 243 \\
\hline Henry & -169 & 265 & -6.8 & -34.9 & 42.5 & 243 \\
\hline Muller1 & -230 & 307 & -9.0 & -37.8 & 38.1 & 299 \\
\hline Muller1 (BC) & -81 & 281 & -1.7 & -30.8 & 47.0 & 228 \\
\hline Schofield & -134 & 306 & -5.0 & -36.2 & 50.4 & 258 \\
\hline $\mathrm{FAO}$ & -106 & 290 & -3.6 & -34.7 & 50.3 & 239 \\
\hline \multicolumn{7}{|c|}{ Equation for both normal weight and obese subjects } \\
\hline Muller2 & 107 & 260 & 7.4 & -23.3 & 57.3 & 232 \\
\hline Muller2 (BC) & -91 & 282 & -2.3 & -30.6 & 44.3 & 231 \\
\hline Mifflin & -257 & 254 & -11.3 & -37.7 & 35.1 & 289 \\
\hline Mifflin (BC) & -513 & 304 & -23.7 & -50.9 & 29.1 & 517 \\
\hline De Lorenzo & -112 & 246 & -4.0 & -30.1 & 43.6 & 211 \\
\hline Owen & -439 & 282 & -20 & -42.7 & 17.9 & 445 \\
\hline Owen (BC) & -592 & 304 & -27.7 & -53.6 & 23.0 & 594 \\
\hline Korth & -157 & 256 & -6.2 & -34.2 & 43.4 & 234 \\
\hline Korth (BC) & -289 & 294 & -18.6 & -44.2 & 50.1 & 330 \\
\hline Johnstone (BC) & -128 & 247 & -5.0 & -33.3 & 49.4 & 217 \\
\hline Livingstone & -291 & 277 & -12.5 & -39.1 & 34.1 & 319 \\
\hline \multicolumn{7}{|c|}{ Equation for obese subjects } \\
\hline Lazzer & -154 & 246 & -6.0 & -30.4 & 38.7 & 225 \\
\hline Lazzer (BC) & -176 & 301 & -6.5 & -38.9 & 55.6 & 267 \\
\hline Muller3 & 124 & 255 & 8.1 & -22.6 & 57.8 & 234 \\
\hline Muller3 (BC) & 47 & 259 & 4.4 & -25.7 & 54.1 & 213 \\
\hline Huang & -260 & 251 & -11.4 & -35.8 & 31.1 & 290 \\
\hline Huang (BC) & -258 & 247 & -11.3 & -35.6 & 31.9 & 286 \\
\hline Bernstein & -531 & 277 & -24.7 & -45.7 & 12.6 & 532 \\
\hline Bernstein (BC) & -579 & 271 & -27.4 & -50.8 & 18.3 & 580 \\
\hline
\end{tabular}

Abbreviations: $\mathrm{BC}$, body composition; Max, maximum; REE, resting energy expenditure; RMSE, root mean square error. Average REE measured with indirect calorimetry $=2028 \pm 388 \mathrm{kcal}$ per day. ${ }^{\mathrm{a}}$ Mean percentage error between predictive equations and measured value.
Generally, only a few equations showed an accuracy within the $\pm 10 \%$ range and included more than $55 \%$ of the REE values. These equations were HB, Henry, Schofield, FAO/WHO/UNU, De Lorenzo and Korth equations in males (Figure 1a) and only the Johnstone $(B C)$ equation in females (Figure $1 \mathrm{~b}$ ).

PREE-MREE differences, bias, RMSE and percentage of accurate predictions in Group 1

The smallest PREE-MREE difference was $+35 \mathrm{kcal}$ per day from the Muller3 $(B C)$ equation in males and -9 kcal per day using the Lazzer (BC) equation in females. The lowest percentage bias was found for the Korth equation in males $(-0.4 \%$, RMSE $224 \mathrm{kcal}$ per day), whereas the FAO/WHO/UNU and Lazzer-BC equations showed the smallest percentage of bias in females (-0.5, 0.9\%; RMSE 177, 173 kcal per day, respectively; Tables 3a and $b)$.

We found that HB, Henry, Schofield, FAO and Korth equations showed higher accuracy of predictions in males $(57.4 \%, 57.8 \%$, $56.6 \%, 57.8 \%$ and $56.6 \%$, respectively; Figure 2a), while the FAO/WHO/UNU, De Lorenzo, Korth, Johnstone and Lazzer-BC 


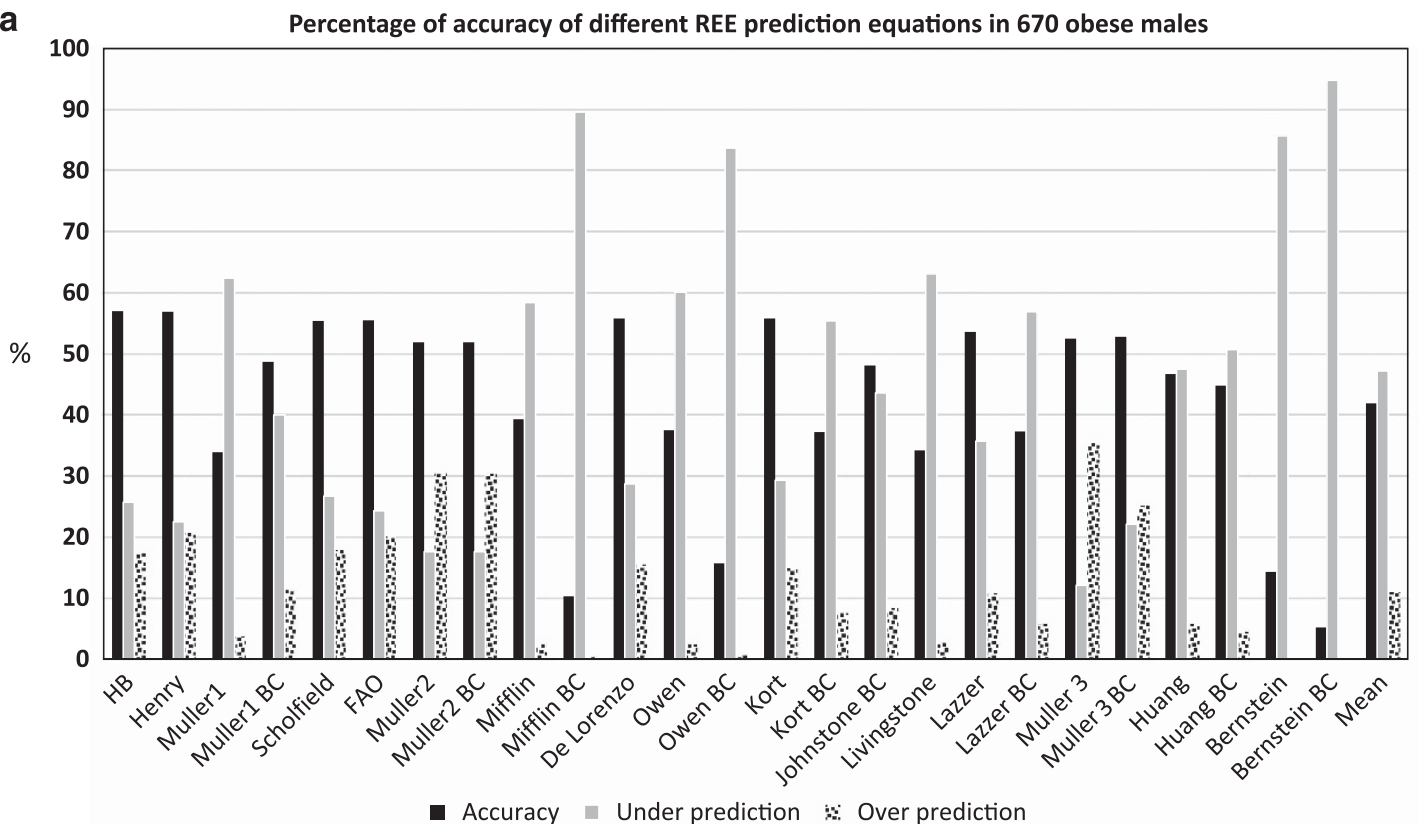

b

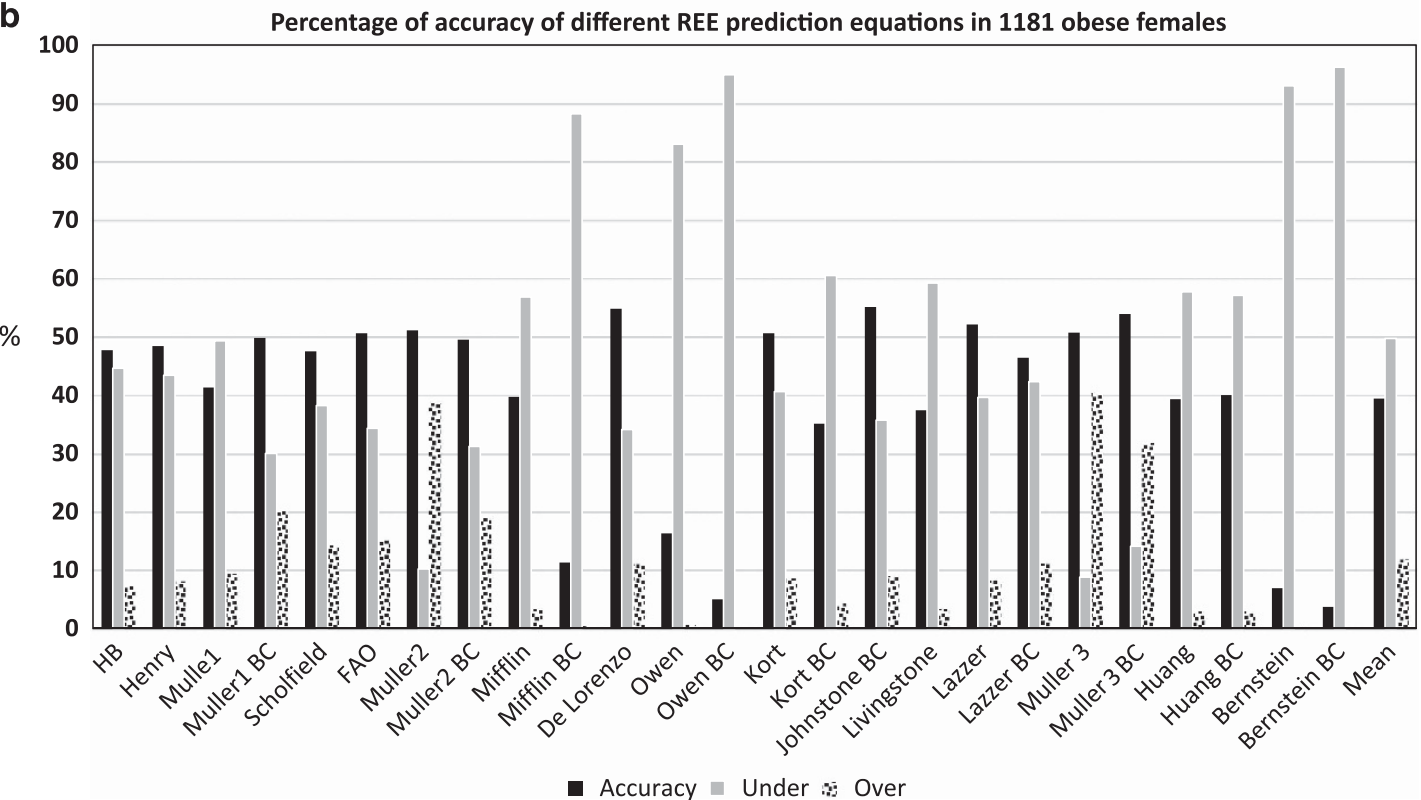

Figure 1. Bland-Altman plot of differences in REE measured by IC and calculated using predictive equations in 670 male (a) and 1181 female (b) obese adults. The dotted lines represent 2 s.d.'s from the mean (limits of agreement).

equations resulted in the most accurate predictions in females $(57.1 \%, 58.3 \%, 57.5 \%, 59.3 \%$ and $58.9 \%$, respectively; Figure 2b).

PREE-MREE difference, bias, RMSE and percentage of accurate predictions in Group 2

The smallest PREE-MREE difference was found in males using the Muller2 equation ( $+29 \mathrm{kcal}$ per day) and in females with the Muller3 (BC) equation (+11 kcal per day). As previously shown, Henry, FAO/WHO/UNU and Muller3 (BC) equations had bias values lower than $1 \%$ in males $(-0.1,-0.9$ and $0.1 \%$; RMSE 273 , 285 and $287 \mathrm{kcal}$ per day), while none of the equations evaluated gave an accurate prediction of REE in females (Tables $3 a$ and $b$, ).
The HB, Henry, Schofield, FAO/WHO/UNU and De Lorenzo equations predicted REE with higher accuracy $(56.7 \%, 57.4 \%$, $56.4 \%, 55.3 \%$ and $55 \%$, respectively) in males (Figure 2a). The Muller3 (BC) equation resulted in the most accurate predictions in females, with $54.6 \%$ accuracy (Figure $2 \mathrm{~b}$ ).

PREE-MREE differences, bias, RMSE and percentage of accurate predictions in Group 3

In group $3\left(\mathrm{BMI}>50 \mathrm{~kg} \mathrm{~m}^{-2}\right)$, the lowest PREE-MREE difference was $-11 \mathrm{kcal}$ per day for males (FAO/WHO/UNU) and $16 \mathrm{kcal}$ per day for females (Muller2). Bias percentages lower than $1 \%$ were found for the $\mathrm{HB}$, Muller2, Schofield and $\mathrm{FAO} / \mathrm{WHO} / \mathrm{UNU}$ equations in males $(-0.5 \%,-0.2 \%,-0.3 \%$ zand $0.7 \%$, respectively) and for the Muller3 $(\mathrm{BC})$ equation in 


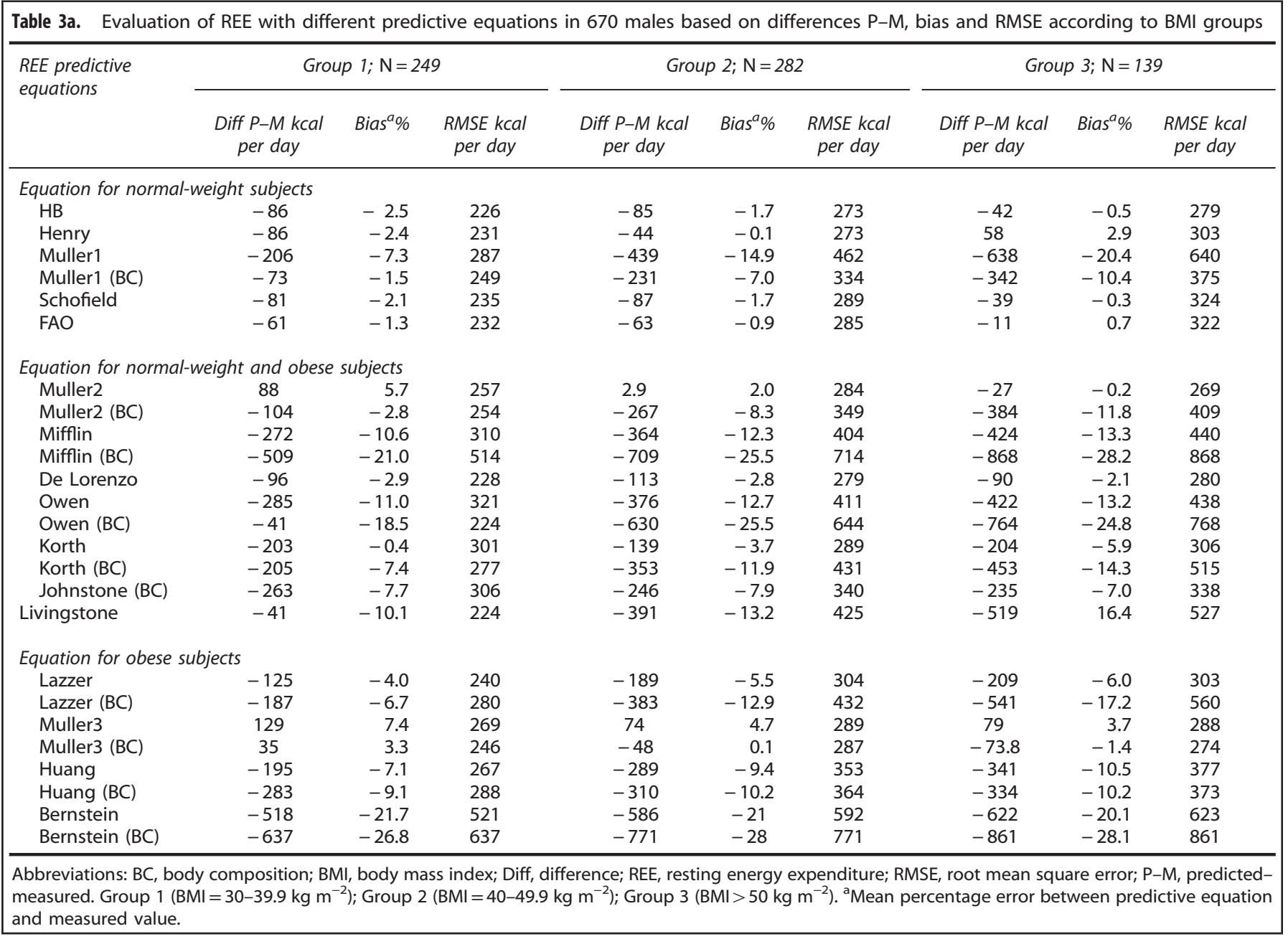

females (-0.4\%; Tables $3 a$ and b). The Muller equation ${ }^{15}$ for overweight and obese subjects, including body composition, gave the most accurate predictions in both sexes (59 and $64 \%$ in males; 58.2 and 59.3 in females, respectively), as shown in Figure 2.

Bland-Altman plots of PREE-MREE differences

Bland-Altman plots of PREE-MREE differences versus mean PREE-MREE values were performed for each equation; eight of these (four for males, four for females) demonstrated the best agreement for PREE and MREE and have been shown in Figure 3 . The selected plots highlight the best agreement.

\section{DISCUSSION}

The present study compared REE measured by IC with REE estimated from several predictive equations in a large sample of obese, Caucasian patients. Accuracy of predictions in the whole sample as well as within BMl subgroups was assessed for each equation. Our findings showed that some of the predictive equations $\mathrm{s}^{3-5,7,18}$ can be used for estimating REE at the population level if the BMl is lower than $40 \mathrm{~kg} \mathrm{~m}^{-2}$. However, none of them can be used to assess individual differences, as they provide inaccurate results for clinical use.
According to the literature, the Mifflin equation ${ }^{6}$ is the best predictive equation for estimating REE in obese people with a BMI range between 30 and $40 \mathrm{~kg} \mathrm{~m}^{-2}$, but no literature was found with a recommendation for predicting REE in severely obese subjects $\left(\mathrm{BMI}>40 \mathrm{~kg} \mathrm{~m}^{-2}\right)$. In fact, a recent systematic review by Madden et al. ${ }^{30}$ reported that the Mifflin equation is recommended for people with BMI values between 30 and $39.9 \mathrm{~kg} \mathrm{~m}^{-2}$, although errors exceed 10 in $25 \%$ of those assessed. Overall, no single predictive equation provides accurate REE estimations for all obese adults. This finding was in accordance with a previous systematic review by Frankenfield et al. ${ }^{27}$ who suggested that the Mifflin St Jeor equation ${ }^{6}$ may be used for overweight and obese subjects (BMI 25-40 $\mathrm{kg} \mathrm{m}^{-2}$ ) but not for those who are severely obese, despite limited data supporting this claim. Similarly, Weijs et al. ${ }^{31}$ found that the Mifflin equation was accurate in estimating REE in overweight and obese adults in the United States (BMI $25-40 \mathrm{~kg} \mathrm{~m}^{-2}$ ), although there currently appears to be no accurate equation for predicting REE in Dutch adults. Despite many studies supporting the use of the Mifflin equation, our results showed that $\mathrm{HB}^{3}{ }^{3}$ Henry, ${ }^{17}$ Schofield, ${ }^{4}$ Muller, ${ }^{18} \mathrm{FAO} / \mathrm{WHO}^{8} \mathrm{UNU}^{5}$ and De Lorenzo ${ }^{19}$ equations were all suitable for predicting REE in our obese population when considering an acceptable PREEMREE difference as lower than 5\%; however, none of these equations showed an accurate prediction ( 55\%) at the individual level. Similar results were previously observed in 
Table 3b. Evaluation of REE with different predictive equations in 1181 females based on differences P-M, bias and RMSE according to BMI groups

\begin{tabular}{|c|c|c|c|c|c|c|c|c|c|}
\hline \multirow{2}{*}{$\begin{array}{l}\text { REE predictive } \\
\text { equations }\end{array}$} & \multicolumn{3}{|c|}{ Group 1; N = 494} & \multicolumn{3}{|c|}{ Group 2; N = 498} & \multicolumn{3}{|c|}{ Group 3; N = 189} \\
\hline & $\begin{array}{c}\text { Diff } P-M \\
k c a l \text { per day }\end{array}$ & Bias $^{\mathrm{a}}$ & $\begin{array}{l}\text { RMSE kcal } \\
\text { per day }\end{array}$ & $\begin{array}{c}\text { Diff } P-M \\
\text { kcal per day }\end{array}$ & Bias $^{\mathrm{a}} \%$ & $\begin{array}{c}\text { RMSE kcal } \\
\text { per day }\end{array}$ & $\begin{array}{c}\text { Diff } P-M \\
\text { kcal per day }\end{array}$ & Bias $^{\mathrm{a}} \%$ & $\begin{array}{c}\text { RMSE kcal } \\
\text { per day }\end{array}$ \\
\hline \multicolumn{10}{|c|}{ Equation for normal-weight subjects } \\
\hline $\mathrm{HB}$ & -79 & -3.2 & 172 & -222 & -9.2 & 267 & -338 & -12.5 & 366 \\
\hline Henry & -96 & -4.3 & 181 & -197 & -8.0 & 263 & -284 & -10.3 & 355 \\
\hline Muller1 & -57 & -1.6 & 186 & -296 & -12.5 & 330 & -509 & -19.3 & 515 \\
\hline Muller1 (BC) & 44 & 4.2 & 182 & -333 & -4.7 & 240 & -268 & -9.5 & 318 \\
\hline Schofield & -53 & -1.7 & 185 & -159 & -6.4 & 272 & -278 & -10 & 410 \\
\hline FAO & -32 & -0.5 & 177 & -131 & -5.0 & 250 & -235 & -8.2 & 368 \\
\hline \multicolumn{10}{|c|}{ Equation for normal-weight and obese subjects } \\
\hline Muller2 & 178 & 11.9 & 235 & 70.8 & 5.1 & 230 & 16 & 2.0 & 229 \\
\hline Muller2 (BC) & 36 & 3.7 & 181 & -145 & -5.2 & 243 & -284 & -10.1 & 328 \\
\hline Mifflin & -168 & -8.5 & 213 & -294 & -12.7 & 319 & -394 & -14.9 & 411 \\
\hline Mifflin (BC) & -348 & -18.7 & 356 & -579 & -26.1 & 580 & -773 & -30.2 & 772 \\
\hline De Lorenzo & -44 & -1.3 & 168 & -144 & -6.5 & 228 & -210 & -7.3 & 280 \\
\hline Owen & -301 & -15.8 & 309 & -495 & -22 & 498 & -656 & -25.4 & 656 \\
\hline Owen (BC) & -427 & -23.3 & 430 & -658 & -30 & 658 & -852 & -33.5 & 852 \\
\hline Korth & -66 & -2.6 & 176 & -194 & -8 & 253 & -298 & -10.9 & 335 \\
\hline Korth (BC) & -157 & -7.7 & 221 & -346 & -15 & 372 & -488 & -18.6 & 502 \\
\hline Johnstone (BC) & -70 & -2.9 & 173 & -158 & -6.2 & 238 & -198 & -6.9 & 274 \\
\hline Livingstone & -159 & -7.8 & 206 & -336 & -14.5 & 353 & -515 & -19.6 & 521 \\
\hline \multicolumn{10}{|c|}{ Equation for obese subjects } \\
\hline Lazzer & -85 & -3.6 & 173 & -187 & -7.5 & 248 & -249 & -8.9 & 302 \\
\hline Lazzer (BC) & -9 & 0.9 & 173 & -241 & -10 & 288 & -441 & -16.6 & 459 \\
\hline Muller3 & 173 & 11.6 & 232 & 95 & 6.2 & 234 & 73 & 4.3 & 238 \\
\hline Muller3 (BC) & 119 & 8.4 & 203 & 11 & 2.2 & 219 & -43 & -0.4 & 228 \\
\hline Huang & -176 & -8.8 & 215 & -298 & -12.8 & 322 & -384 & -14.4 & 401 \\
\hline Huang (BC) & -185 & -9.4 & 218 & -293 & -12.6 & 319 & -357 & -13.3 & 378 \\
\hline Bernstein & -397 & -21.5 & 400 & -584 & -26.4 & 584 & -742 & -28.9 & 742 \\
\hline Bernstein (BC) & -458 & 25.2 & 460 & -630 & -28.7 & 630 & -761 & -29.8 & 761 \\
\hline
\end{tabular}

Abbreviations: $\mathrm{BC}$, body composition; $\mathrm{BMI}$, body mass index; Diff, difference; REE, resting energy expenditure; RMSE, root mean square error; $\mathrm{P}-\mathrm{M}$, predicted-measured. Group $1\left(\mathrm{BMI}=30-40 \mathrm{~kg} \mathrm{~m}^{-2}\right)$; Group $2\left(\mathrm{BMI}=40-50 \mathrm{~kg} \mathrm{~m}^{-2}\right)$; Group $3\left(\mathrm{BMI}>50 \mathrm{~kg} \mathrm{~m}^{-2}\right)$. ${ }^{\mathrm{a}}$ Mean percentage error between predictive equation and measured value.

obese adolescents, which showed that, although some predictive equations, such as the Lazzer equation, were suitable for predicting REE at the population level, the accuracy of these predictions did not reach $50 \%$ at the individual level. ${ }^{32}$

On the basis of our results, and in light of the findings reported by other investigators, it can be concluded that obese-specific equations do not necessarily predict the REE of an obese population more accurately than those obtained from normalweight subjects. In addition, despite what previous studies have suggested, we observed that including body composition variables, such FM and FFM assessed by BIA, did not significantly improve the accuracy of predictions. ${ }^{10,31}$ With obesity, especially severe obesity, there can be variance in the distribution of FM (central versus peripheral, android versus gynoid) ${ }^{33}$ and fluid distribution (edema, lymphedema) that results in body segments that are not cylindrical, which contradicts the primary assumption of BIA measurements. ${ }^{34}$ In these cases, tissue hydration status is not constant across BMI categories, further contradicting the second assumption of BIA measurements. ${ }^{34}$ In fact, obesity is associated with a state of general 'overhydration', with excess total body water and an altered ratio of extracellular water to intracellular water. Elevated total body water and extracellular water result in overestimations of FFM and thereby underestimate FM with an increasingly lower accuracy for higher levels of obesity. ${ }^{34,35}$
When the study population was split into three groups according to BMI, prediction accuracy was further reduced in the two heaviest groups, especially in females. As a result, none of the predictive equations specifically obtained from obese subjects $7,25,26$ were well fitted to our female sample, with the exception of the Muller equation, ${ }^{18}$ which was accurate in 55 and $59 \%$ of obese females (Groups 2 and 3, respectively). Comparatively, the Lazzer equation, ${ }^{7}$ which was developed in obese Italian females, was accurate only in Group 1 (BMI= $30-39.9 \mathrm{~kg} \mathrm{~m}^{-2}$ ). Recently, Jesus et al. ${ }^{36}$ showed that the Muller equation ${ }^{18}$ gave a high percentage of accurate predictions $(\sim 64 \%)$ in patients with BMls higher than $40 \mathrm{~kg} \mathrm{~m}^{-2}$. However, the highest accuracy was achieved by the Huang equation ${ }^{25}$ (65-66\% of patients). Horie et al. ${ }^{9}$ developed a new equation specifically to estimate REE in 120 severely obese subjects $(\mathrm{BMI}=46.9 \pm 6.2)$; however, this equation did not improve the prediction accuracy in our sample (data not shown). In addition, although Dobratz et al. ${ }^{37}$ reported that the Mifflin equation was accurate in 14 severely obese women (BMI $49.8 \pm 6.2 \mathrm{~kg} \mathrm{~m}^{-2}$ ), their estimates of REE showed many limitations, as reported by the authors, including the small sample size, inconsistent menstrual status and impaired glucose control.

There are several factors that may contribute to errors when estimating REE, especially in severely obese patients. The extreme excess of adipose tissue, being less meta- 


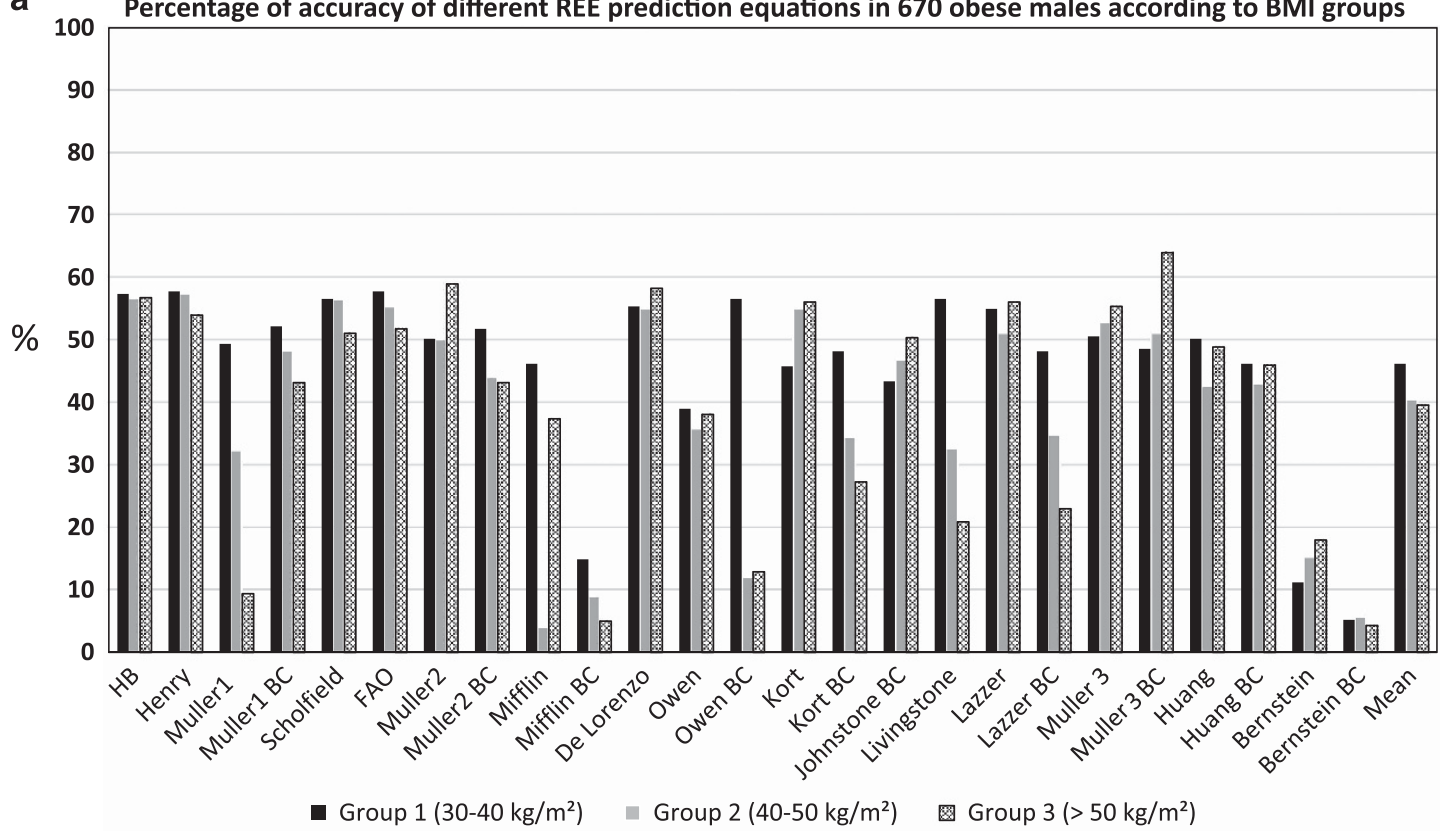

b Percentage of accuracy of different REE prediction equations in 1181 obese females according to BMI groups

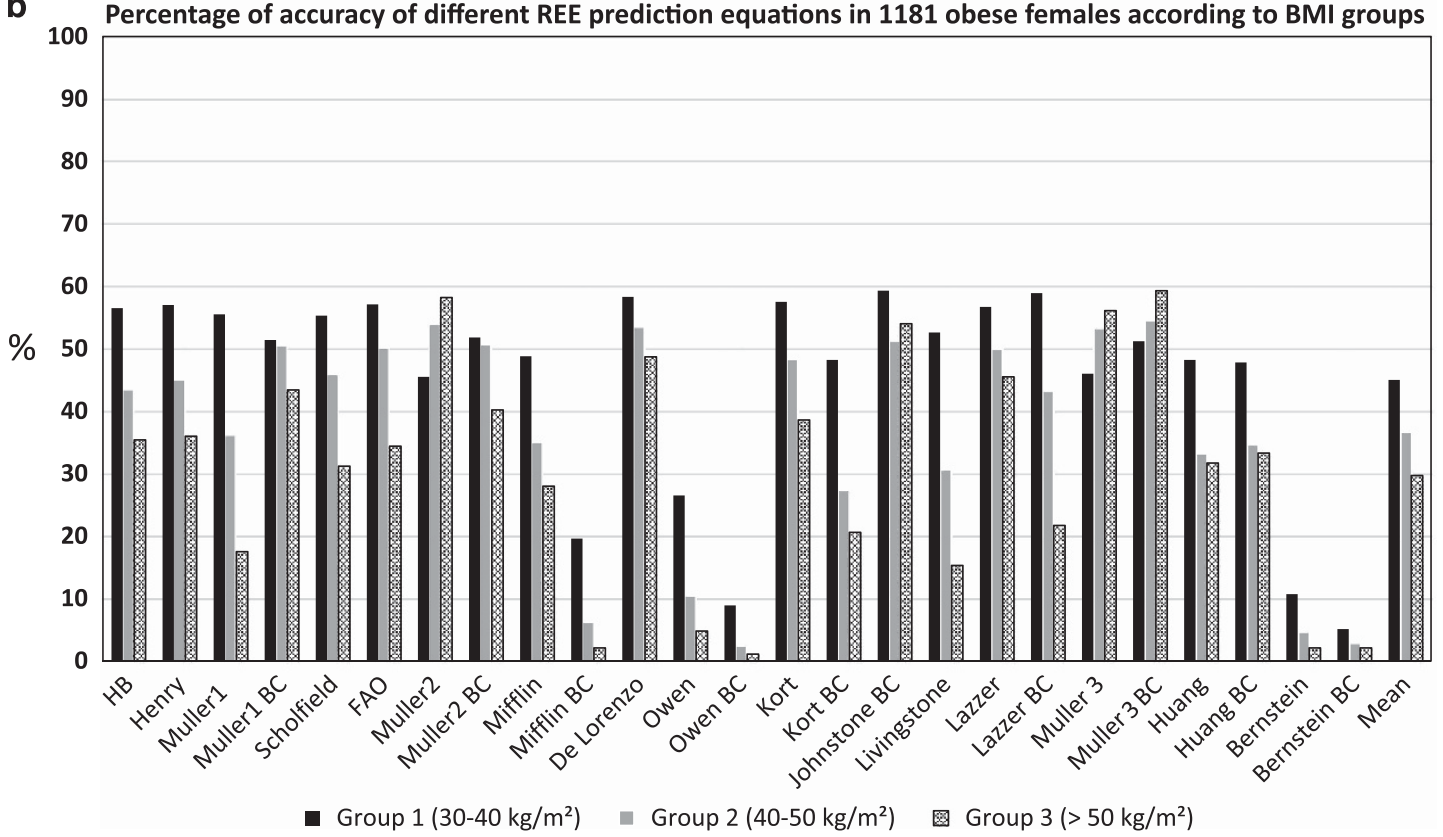

Figure 2. Accuracy of prediction equations for measurements of REE within $\pm 10 \%$ using each equation in 670 male and 1181 female obese subjects $(\mathbf{a}, \mathbf{b})$, respectively.

bolically active than FFM, can reduce efficacy of estimating REE. ${ }^{38}$ There is also a lack of consensus concerning the correct weight to use in REE estimations in these individuals (current, ideal or adjusted body weight). Genders should be separated in statistical analyses to avoid any confounding factors when comparing IC data, ${ }^{8}$ as was done in this study. The variability in REE measurements due to inaccuracy of IC measurements should also be considered. ${ }^{39}$ Finally, although BIA has some problems when used in severely obese cases because of FM distribution and hydration status, dual-energy X-ray absorptiometry, the gold standard method for body composition evaluation, cannot be performed for body weights above $120 \mathrm{~kg}$.
In conclusion, this study showed a wide variation for predicting REE that was higher for body composition-based equations than weight-based equations; however, accuracy was very low for all the predictive equations analyzed. This finding highlights the importance of measuring REE by IC, as we found that REE was underestimated in roughly $50 \%$ of subjects, indicating that PREE was much lower than MREE. A reduced REE estimate provides inadequate energy intake values and thus impairs diet compliance, which can affect weight loss and management. On the basis of our results, it would be useful to validate REE predictive equations specifically for patients with a BMI higher than $40 \mathrm{~kg} \mathrm{~m}^{-2}$ to improve their effectiveness in clinical practice. 
a
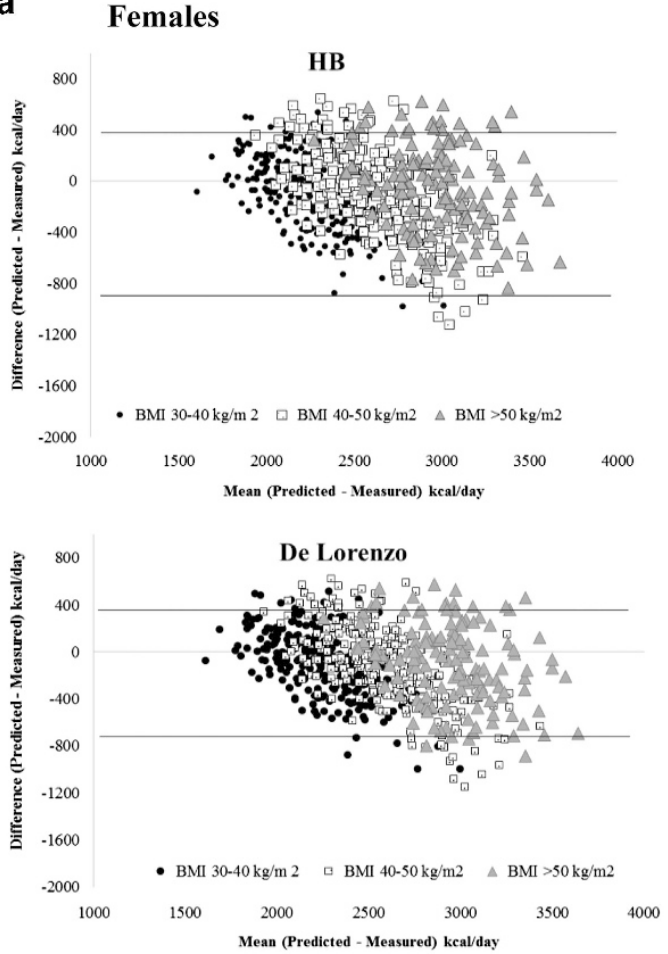

b
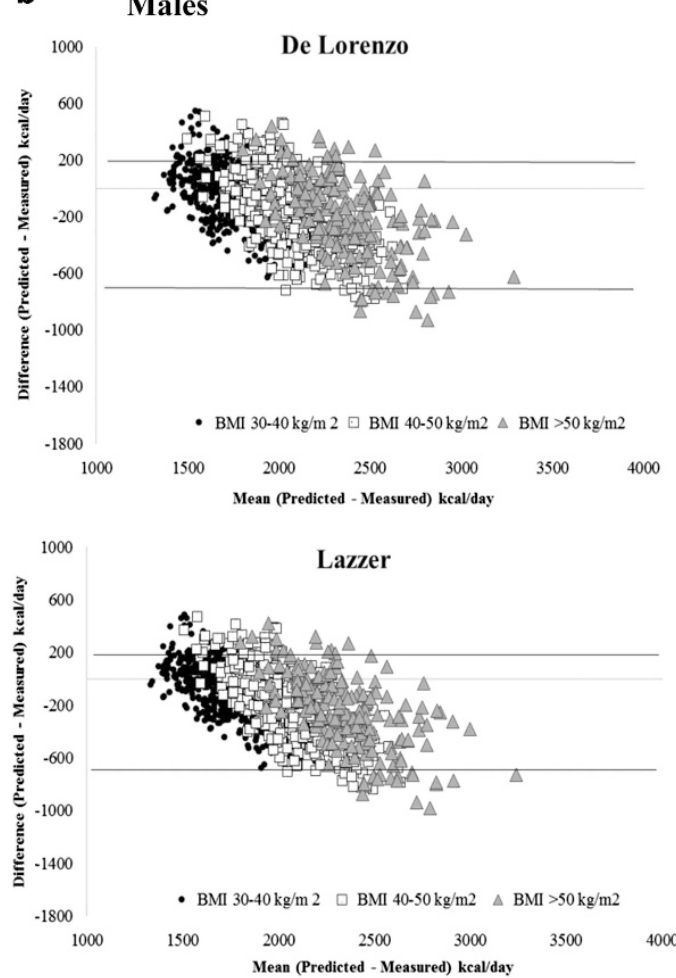
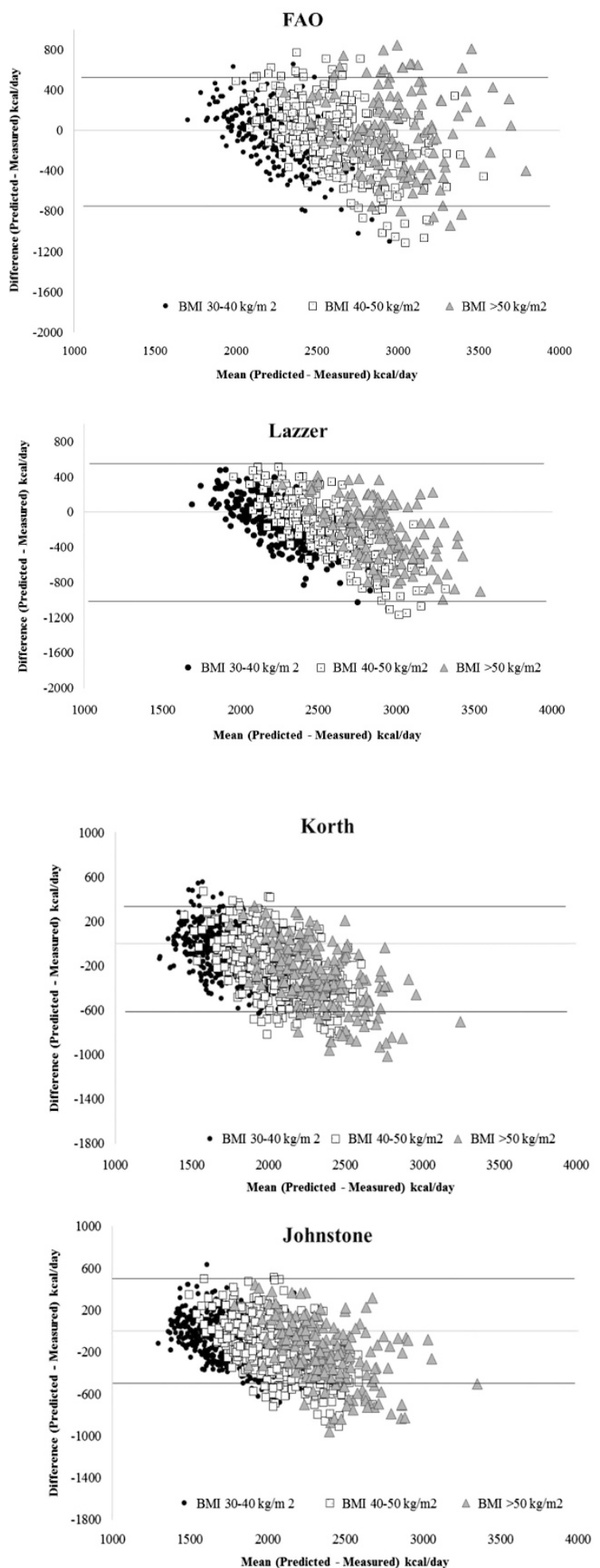

Figure 3. Accuracy of prediction equations for measurements of REE within $\pm 10 \%$ using each equation according to BMI subgroups in 670 male and 1181 female obese subjects $(\mathbf{a}, \mathbf{b})$, respectively. 


\section{CONFLICT OF INTEREST}

The authors declare no conflict of interest.

\section{REFERENCES}

1 Pinheiro Volp AC, Esteves de Oliveira FC, Duarte Moreira Alves R, Esteves EA, Bressan J. Energy expenditure: components and evaluation methods. Nutr Hosp 2011; 26: 430-440.

2 Marra M, Scalfi L, Covino A, Esposito-Del Puente A, Contaldo F. Fasting respiratory quotient as a predictor of weight changes in non-obese women. Int $J$ Obes Relat Metab Disord 1998; 22: 601.

3 Harris JA, Benedict FG. A biometric study of human basal metabolism. Proc Natl Acad Sci USA 1918; 4: 370-373.

4 Schofield WN. Predicting basal metabolic rate, new standards and review of previous work. Hum Nutr Clin Nutr 1985; 39: 5-41.

$5 \mathrm{FAO} / \mathrm{WHO} / \mathrm{UNU}$. Energy and protein requirements. Report of a joint FAO/WHO/ UNU expert consultation. World Health Organ Tech Rep Ser 1985; 724: 1-206.

6 Mifflin MD St, Jeor ST, Hill LA, Scott BJ, Daugherty SA, Koh YO. A new predictive equation for resting energy expenditure in healthy individuals. Am J Clin Nutr 1990; 51: 241-247.

7 Lazzer S, Agosti F, Silvestri P, Derumeaux-Burel H, Sartorio A. Prediction of resting energy expenditure in severely obese Italian women. J Endocrinol Invest 2007; 30: 20-27.

8 De Luis DA, Aller R, Izaola O. Resting energy expenditure and insulin resistance in obese patients, differences in women and men. Eur Rev Med Pharmacol Sci 2006; 10: 285-289.

9 Horie LM, Gonzales MC, Torrinhas RS, Cecconello I, Waitzberg DL. New specific equation to estimate resting energy expenditure in severely obese patients. Obesity 2011; 19: 1090-1094.

10 Wilms B, Schmid SM, Ernst B, Thurnheer M, Mueller MJ, Schultes B. Poor prediction of resting energy expenditure in obese women by established equation. Metabolism 2010; 59: 1181-1189.

11 Blauw LL, Boon MR, Rosendaal FR, de Mutsert R, Gast KB, van Dijk KW et al. Smoking is associated with increased resting energy expenditure in the general population: the NEO study. Metabolism 2015; 64: 1548-1555.

12 Kyle UG, Bosaeus I, De Lorenzo AD, Deurenberg P, Elia M, Gómez JM et al. Bioelectrical impedance analysis--part I: review of principles and methods. Clin Nutr 2004; 23: 1226-1243.

13 Lukaski HC. Biological indexes considered in the derivation of the bioelectrical impedance analysis. Am J Clin Nutr 1996; 64: 397-404.

14 Kushner RF. Bioelectrical impedance analysis: a review of principles and applications. J Am Col Nutr 1992; 11: 99-209.

15 Elia M, Livesey G. Theory and validity of indirect calorimetry during net lipid synthesis. Am J Clin Nutr 1988; 47: 591-607.

16 Weir JB. New methods for calculating metabolic rate with special reference to protein metabolism. J Physiol 1949; 109: 1-9.

17 Henry CJ. Basal metabolic rate studies in humans: measurement and development of new equations. Public Health Nutr 2005; 8: 1133-1152.

18 Müller MJ, Bosy-Westphal A, Klaus S, Kreymann G, Lührmann PM, Neuhäuser-Berthold $\mathrm{M}$ et al. World Health Organization equations have shortcomings for predicting resting energy expenditure in person from a modern, affluent population: generation of a new reference standard from a retrospective analysis of German database of resting energy expenditure. Am J Clin Nutr 2004; 80: 1379-1390.

19 De Lorenzo A, Tagliabue A, Andreoli A, Testolin G, Comelli M, Deuremberg P. Measured and predicted resting metabolic rate in Italian males and females, aged 18-59 y. Eur J Clin Nutr 2001; 55: 208-214.

20 Owen OE, Kavle E, Owen RS, Polansky M, Caprio S, Mozzoli MA et al. A reappraisal of caloric requirements in healthy women. Am J Clin Nutr 1986; 44: 1-19.

21 Owen OE, Holup JL, D'Alessio DA, Craig ES, Polansky M, Smalley KJ et al. A reappraisal of the caloric requirements of men. Am J Clin Nutr 1987; 46: 875-885.

22 Korth O, Bosy-Westphal A, Zschoche P, Glüer CC, Heller M, Müller MJ. Influence of methods used in body composition analysis on the prediction of resting energy expenditure. Eur J Clin Nutr 2007; 61: 582-589.
23 Johnstone AM, Rance KA, Murison SD, Duncan JS, Speakman JR. Additional anthropometric measures may improve the predictability of basal metabolic rate in adult subjects. Eur J Clin Nutr 2006; 60: 1437-1444.

24 Livingston $\mathrm{EH}$, Kohlstadt I. Simplified resting metabolic rate-predicting formulas for normal-sized and obese individuals. Obes Res 2005; 13: 1255.

25 Huang KC, Kormas N, Steinbeck K, Loughnan G, Caterson ID. Resting metabolic rate in severely obese diabetic and nondiabetic subjects. Obes Res 2004; 12: 840-845.

26 Bernstein RS, Thornton JC, Yang MU, Wang J, Redmond AM, Pierson RN et al. Prediction of the resting metabolic rate in obese patients. Am J Clin Nutr 1983; 37: 595-602.

27 Frankenfield D, Roth-Yousey L, Compher C, Evidence Analysis Working Group. Comparison of predictive equations for resting metabolic rate in healthy nonobese and obese adults: a systematic review. J Am Diet Assoc 2005; 105: 775-789.

28 Frankenfield DC, Rowe WA, Smith JS, Cooney RN. Validation of several established equations for resting metabolic rate in obese and non-obese people. J Am Diet Assoc 2003; 103: 1152-1159.

29 Bland JM, Altman DG. Statistical methods for assessing agreement between two methods of clinical measurement. Lancet 1986; 1: 307-310.

30 Madden AM, Mulrooney HM, Shah S. Estimation of energy expenditure using prediction equations in overweight and obese adults: a systematic review. J Hum Nutr Diet 2016; 29: 458-476.

31 Weijs PJ. Validity of predictive equations for resting energy expenditure in US and Dutch overweight and obese class I and II adults aged 18-65 y. Am J Clin Nutr 2008; 88: 959-970.

32 Marra M, Montagnese C, Sammarco R, Amato V, Della Valle E, Franzese A et al. Accuracy of predictive equations for estimating resting energy expenditure in obese adolescents. J Pediatr 2015; 166: 1390-6.e1.

33 Das SK. Body composition measurement in severe obesity. Curr Opin Clin Nutr Metab Care 2005; 8: 602-606.

34 Kyle UG, Bosaeus I, De Lorenzo AD, Deurenberg P, Elia M, Manuel Gomez J et al. Bioelectrical impedance analysis-part II: utilization in clinical practice. Clin Nutr 2004; 23: 1430-1453.

35 Lukaski HC. Evolution of bioimpedance: a circuitous journey from estimation of physiological function to assessment of body composition and a return to clinical research. Eur J Clin Nutr 2013; 67(Suppl 1): S2-S9.

36 Jésus $\mathrm{P}$, Achamrah N, Grigioni S, Charles J, Rimbert A, Folope $V$ et al. Validity of predictive equations for resting energy expenditure according to the body mass index in a population of 1726 patients followed in a nutrition unit. Clin Nutr 2015; 34: 529-535.

37 Dobratz JR, Sibley SD, Beckman TR, Valentine BJ, Kellogg TA, Ikramuddin S et al. Predicting energy expenditure in extremely obese women. JPEN 2007; 31: 217-227.

38 Das SK, Roberts SB, Kehayias JJ, Wang J, Hsu LK, Shikora SA et al. Body composition assessment in extreme obesity and after massive weight loss induced by gastric bypass surgery. Am J Physiol Endocrinol Metab 2003; 284: E1080-E1088.

39 Bader N, Bosy- Westphal A, Dilba B, Muller MJ. Intra - and interindividual variability of resting energy expenditure in healthy male subjects-biological and methodological variability of resting energy expenditure. Br J Nutr 2005; 94: 843-849.

(c) (i) $\Theta$ This work is licensed under a Creative Commons Attributionc. NonCommercial-NoDerivs 4.0 International License. The images or other third party material in this article are included in the article's Creative Commons license, unless indicated otherwise in the credit line; if the material is not included under the Creative Commons license, users will need to obtain permission from the license holder to reproduce the material. To view a copy of this license, visit http:// creativecommons.org/licenses/by-nc-nd/4.0/

(c) The Author(s) 2017

Supplementary Information accompanies this paper on International Journal of Obesity website (http://www.nature.com/ijo) 